\title{
Hittites and Arzawans: a view from western Anatolia
}

\author{
Naoíse Mac Sweeney \\ University of Cambridge
}

\begin{abstract}
There has been much recent research in archaeology on the dynamics of imperial systems, and valuable work has been done on the complex relationships between the Hittite state and groups on its imperial periphery. The nature of the available source material means that these relationships are usually studied from a Hittite perspective, and that interactions with the Hittites are often seen as centrally important for these groups. In this paper, however, it is argued that archaeological evidence can be used to gain insight into alternative views - views which may not necessarily privilege relationships with the Hittites over those with other groups. One well-documented example of such a group is Arzawa, a quarrelsome coalition of principalities in western Anatolia. This paper will focus on the western Anatolian site of Beycesultan, caught between the Hittite and Arzawan heartlands. It will show that people at Beycesultan did not define themselves primarily in relation to either the Hittites or the Arzawan confederacy, but had their own dynamic and shifting world-view.
\end{abstract}

\section{Özet}

İmparatorluk sistemlerinin dinamikleri konusunda pek çok yeni arkeolojik araştırmalar yapılmıştır. Bu araştırmalara dayanarak, Hitit devleti ile çevresindeki gruplar arasındaki karmaşık ilişkileri inceleyen birçok değerli çalışma yapılmıştır. Mevcut olan kaynakların doğası gereği, bu ilişkiler genellikle Hitit bakış açısıyla incelenmekte ve çoğunlukla Hititlerle etkileşimin bu gruplar için çok önemli olduğu varsayılmaktadır. Ancak, bu makale arkeolojik kanıtların farklı bakış açılarına sahip olabilmek için kullanılabileceğini savunmaktadır - ki bu bakış açısı, Hititlerle olan ilişkilerinin bu gruplara ayrıcalık sağlaması gerekmediğidir. Bunlar arasında iyi belgelenmiş olan bir örnek de, batı Anadolu'daki savaş̧̧ beyliklerin koalisyonundan oluşan Arzawa grubudur. Bu makale batı Anadolu'daki Hitit ve Arzawa merkezlerinin arasında sıkışmış Beycesultan yerleşimi üzerinde yoğunlaşmaktadır ve aslında Beycesultan halkının kendilerini öncelikli olarak Hitit veya Arzawa birliklerine ait görmediklerini, farklı dinamiklere ve değişken bir dünya görüşüne sahip bir toplum olarak gördüklerini ortaya koyacaktır.

$\mathrm{T}$ he last decade has seen an upsurge of archaeological interest in marginal areas, peripheral regions and border zones, in tune with new movements in postcolonial theory and the anthropology of cultural contact (for example, van Dommelen 1998; Keay, Terrenato 2001; Lyons, Papadopoulos 2002; Dusinberre 2003; Gosden 2004; Hodos 2006; Riva, Vella 2006). This is a trend which has been particularly popular in Mediterranean archaeology, and which has also made itself felt in the recent research undertaken on the Hittite Empire. Great strides forward have been made in the study of the various different states and peoples on the Hittite imperial periphery; contributing not just to our knowledge of these groups specifically, but also to our understanding of the Hittite Empire itself. The kingdom of Tarhuntassa in southern Anatolia is coming into everclearer focus. New inscriptions have been deciphered, bearing witness to Tarhuntassa's considerable political independence from, yet close dynastic connections to Hatti, and new evidence has come to light regarding its geographic location (Hawkins 1995a; Dinçol 1998). A more detailed picture is also emerging of the northern neighbours of the Hittites, with archaeological projects in Paphlagonia uncovering new insights into Kaška social 
organisation and Kaška-Hittite relations (Matthews 2000; Glatz, Matthews 2005; Schoop 2006a). Perhaps, however, the most dramatic developments have been in our knowledge of western Anatolia in the Late Bronze Age and of this region's complex interactions with the Hittites (for example, Gunter 2006; papers in Collins et al. 2008).

Hittite sources refer to an entity in western Anatolia known as 'Arzawa' - a term which, at times, seems to imply an active political unit and, at others, appears merely to denote a vague geographical area (Garstang, Gurney 1959: 75-109; Heinhold-Kramer 1977). In either case, the territory of Arzawa seems to have encompassed most of the Anatolian peninsula west of the plateau, excluding the Troad in the far north and the Lycian highlands in the far south (Gurney 1975: 16; Hawkins 1998; Bryce 1999: 73-74). Whatever its original scope, the term was regularly used in the Hittite sources to refer to coalitions against Hatti based in western Anatolia (Lloyd 1956: 154; Bryce 1999: 151). Arzawan coalitions are recorded at several points throughout Hittite history from the Old Kingdom onwards, but it was not until the 13th century BC that a truly threatening alliance was formed. At this time, a local ruler named Uhhaziti managed to unite the majority of the Arzawan groups into a pan-Arzawan confederacy. The confederacy itself was extremely short-lived, as the Hittite king Mursili II soon intervened to break it up, waging a fierce campaign against Uhhaziti and eventually imposing a peace which divided Arzawa into three separate kingdoms: Mira and Kuwaliya; Appawiya and the Seha River Land; and Hapalla (Grélois 1988; Beckman 1996: 10-12).

The Hittite documents record almost constant shifts of allegiance and political intriguing in Arzawa, implying that the region was not naturally a single homogeneous unit but a fluid patchwork of small principalities and independent polities (Macqueen 1975: 40; Bryce 1999: 52; 2006: 76). Some scholars contend that Arzawa would, nonetheless, have been a cultural unit if not a political one, basing their arguments on the idea that western Anatolia was populated by a single ethnolinguistic group - the Luwians (for example, Lloyd 1956: 154; Beekes 2003; Bryce 2006: 117). However, such claims of Luwian unity have been overturned by recent linguistic studies (Yakubovich 2008), and do not fit well with recent archaeological research, which suggests that there was a high degree of micro-regionalism and diversity within western Anatolia in terms of both cultural traits and social practice (Mellaart, Murray 1995: 105; Mountjoy 1998; Bayne 2000; Basedow 2002; Cline 2008). In addition, it should be noted that such attempts to ascribe an ethnic consciousness on the basis of linguistic or cultural similarity do not consider sufficiently the constructed nature of ethnicity. As now widely recognised, ethnicity does not automatically emerge from traits such as language or material culture style, but is instead actively created and cultivated (Jones 1997; Mac Sweeney 2009). Arzawa therefore emerges as a geographical region composed of several different political, social, cultural and also linguistic groups.

The archaeological record has yielded very little evidence for direct Hittite involvement in either western Anatolia generally or in the area of the Arzawan confederacy in particular (Glatz 2006: 349; 2009; Sagona, Zimansky 2009: 285). It is notable that classic signs of Hittite influence, such as administration systems, élite symbols and standardised modes of pottery production, are all conspicuously absent (Mellaart, Murray 1995: 108; Seeher 2005: 40). It therefore seems that while there were doubtless some individual instances of Hittite intervention in the region, western Anatolia was never fully integrated into either the Hittite political or cultural spheres. Increasingly, new evidence suggests that some western Anatolian groups retained their strength and independence throughout the Late Bronze Age and even expanded their influence at the expense of the Hittite state during the transition into the Early Iron Age. Prime amongst these was Mira, a state Mursili II claimed as one of his client principalities, but which emerged as a formidable power in its own right only a few decades after this claim was made (Hawkins 1998; 2002; Sagona, Zimansky 2009: 285).

Recent research has therefore shed valuable new light on the neighbours of the Hittite Empire to the north, the south and, especially, the west, often showing them to be more independent of the Hittites than had hitherto been thought. While previous approaches concentrated on how neighbouring groups were perceived by the Hittites, these new studies focus instead on how these groups themselves perceived the Hittites. This is an important shift in disciplinary thinking. Nonetheless, when studying these groups, interactions with the Hittites dominate the research questions. Little room is made for the possibility that such groups did not define themselves solely, or even primarily, in terms of their interactions with the Hittites. It is perhaps time, therefore, to consider these diverse groups on their own terms. For them, the Hittites may have been only one amongst many different neighbours with which they interacted. It is even possible that, for some of these groups, their dealings with the Hittite Empire may have been relatively minor considerations in the context of their wider world-view. Put simply, the Hittites may not have been as central a reference point for the various Arzawan groups as we might have hitherto assumed. 
This paper will explore these questions, focusing on one of the groups which was probably involved in the Arzawan confederacy against the Hittites. By examining the archaeological material from one site Beycesultan - in detail, it will attempt to shed light on how people at this site would have viewed both the Hittites and the Arzawan confederacy, uncovering something about their perceptions of and attitudes towards their neighbours on all sides. Beycesultan is one of the key sites in the region, considered to be a type-site for the inland southwestern area (Mellaart, Murray 1995; Bryce 2006: 45). The distinctive nature of the site's material culture and its unusually rich architectural record marked Beycesultan out from the early days of its exploration (Lloyd 1954; 1955), and new excavations have recently been opened by the Ege University under the direction of Dr Eşref Abay. As material from this new project is not yet available for study, this paper will focus on the material uncovered during the 1954-1959 excavations led by Seton Lloyd and James Mellaart. With the site now being reopened, the time is ripe for a reconsideration of past work and discoveries at Beycesultan.

Beycesultan itself lies in the Upper Maeander valley, on one of the main routes between the Aegean coast and the central Anatolian plateau (fig. 1). As such, it would have been located directly between the Hittite and Arzawan heartlands, in the part of Arzawa which was closest to Hatti itself. This area is densely populated with unexplored höyük mounds (Abay, Dedeoğlu 2005), and is also now thought to be the 'Kuwaliya' of the Hittite documents (Hawkins 1998: 31). The population of the site is therefore highly likely to have had frequent contacts with both central Anatolia and western Anatolia throughout the Late Bronze Age. The remains of Beycesultan therefore afford us the opportunity to investigate a community which would have interacted closely both with the Hittites to the east and with the other Arzawan groups to the west. Crucially, they offer us the chance to study how members of one Arzawan group viewed their place in the wider world around them, and how they chose to depict their relationships with both the Hittites and their Arzawan allies.

While both archaeological and documentary history have already told us many things about the practical reality of these relationships, we know almost nothing about how people at Beycesultan thought about their easterly and westerly neighbours. How far did Beycesultan see itself as being part of the world of the central Anatolian plateau, and how far a part of the sociopolitical patchwork of the west? Did people here necessarily see themselves as situated somewhere along a Hittite-Arzawan continuum? By analysing the use of style in material culture, it is possible to gain some insight into these questions.

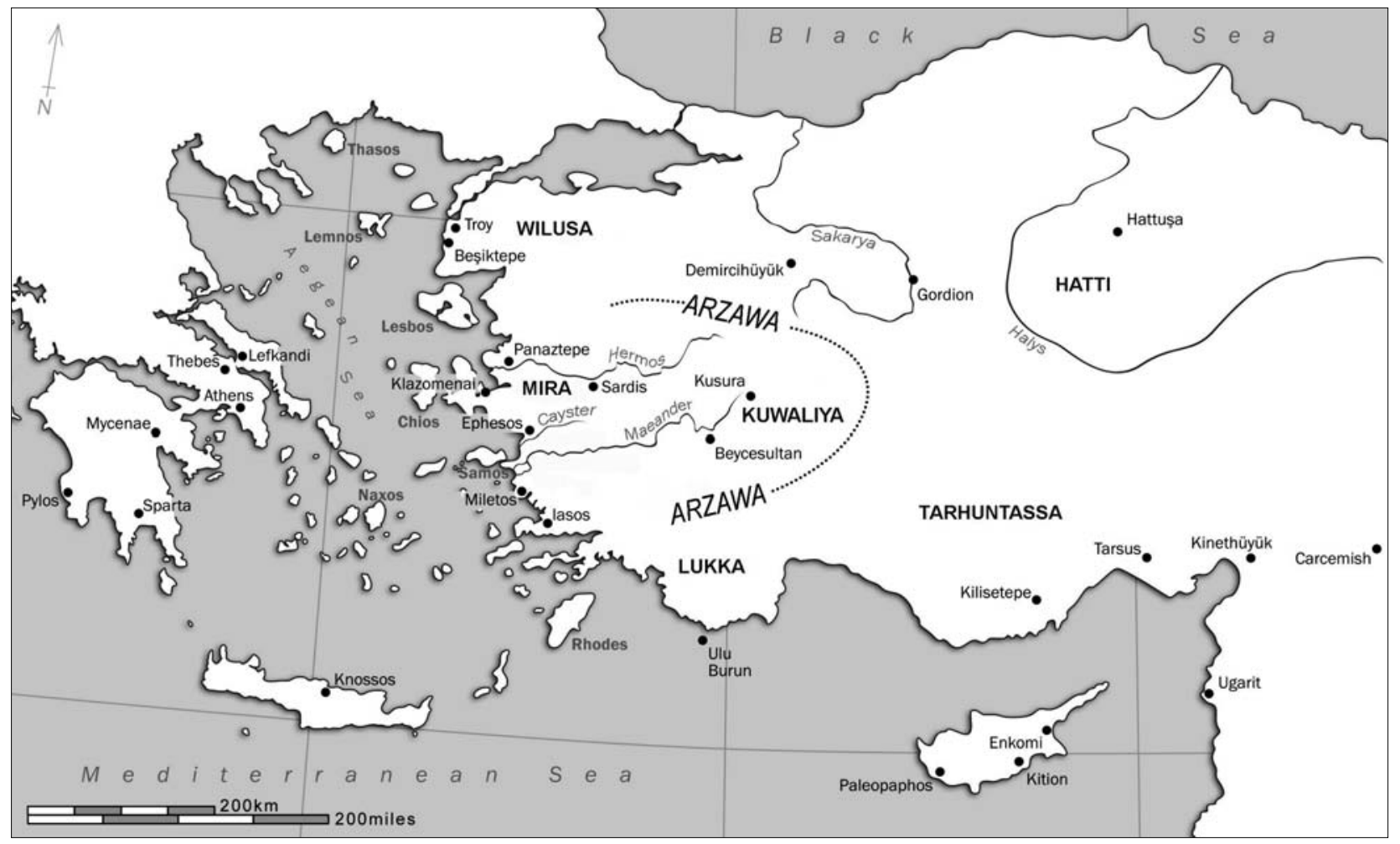

Fig 1. Map of Anatolia and the Aegean during the Late Bronze Age 


\section{Material culture and representing external contacts}

This paper aims to shed some light on how people in Late Bronze Age Beycesultan viewed their neighbours to the west and the east. In order to do this, it will attempt to explore how the people of Beycesultan represented their relationships with their eastern and western neighbours how they understood these relationships, what they thought of them and how they sought to portray them. The paper will not focus on the nature and frequency of Beycesultan's contacts with the Hittites and the various Arzawan groups. Nor will it discuss in detail the evidence for the practical interactions which must have existed between Beycesultan and its neighbours. Rather, it is the representation of these interactions which is of central intrest here. Literary (for example, Hall 1989) and artistic (for example, Cohen 2000) studies are frequently used to investigate how ancient populations represented their external contacts and constructed the external Other. Such studies, however, are less frequently attempted using material culture. Nonetheless, it is still possible to use archaeological evidence in this way.

The use of material culture is both a construct of and actively works to construct social norms and identities (Appadurai 1988; Hodder 1989; Tilley 1989; Jones 1997; Knappett 2005). Theories such as social practice (Bourdieu 1977), embodiment (Rohrer 2007) and performance (Butler 1997) have highlighted how objects and social practices are both influenced by and have an influence on social expectations. It is now widely understood that humans use material culture to 'think through' and to make sense of the world around them (Knappett 2005). These theoretical insights suggest that ideas about the external Other can indeed be constructed through symbolic (as well as visual or verbal) representations of that Other. In such symbolic representations, certain artefacts, objects and social practices function as symbols of the Other. The way such symbols are used and treated then constructs a particular image and perception of that Other. For an archaeological enquiry into such constructions, two processes are therefore key: firstly, the identification of artefacts, objects and social practices which could have functioned as symbols of various external Others; and, secondly, the assessment of how such symbols were used to construct images of these Others.

In the first of these considerations, style is a crucial concept. It is through style that objects recall associations of various external Others, and thereby become symbols of those Others. Theories of style and semiotics suggest that the perception of stylistic difference is dependent on subjective categorisation within a wide framework of inter-relating signs (Tilley 1989: 185-88; Bal, Bryson 1991; Knappett 2005: 86-106). Stylistic recognition therefore relies on the basic cognitive process of 'identification via comparison' to slot an artefact into a mental network of social meaning (Wiessner 1984: 191-95; Gamble 2001: 198). It follows that objects can be symbolic of an external Other, not just by adhering strictly to a foreign style, but also by recalling or evoking that style and awakening associations with a mental category of 'foreign' or 'Other'. Identifying artefacts, objects and social practices which could have functioned as symbols of various external Others is therefore a complex process, focusing less on formal characteristics than on visual cues and overall general appearance. An illustration of this point can be found in the European taste for Chinoiserie in the 18th and 19th centuries (Impey 1977; Jacobsen 1993). During this time, consumers in western Europe developed a taste for oriental styles in textiles, ceramics and decorative furnishings. However, the objects and styles popular in Europe were rarely faithful to original Chinese forms of material culture - instead, they were loose interpretations of oriental styles adapted to a European context. But despite the substantial difference between genuine Chinese objects and Chinoiserie, these items made in a pseudo-Chinese style nonetheless evoked a sense of the exotic Orient for those who bought them.

The second process focuses on the use of these symbolic items, as the treatment of symbols both shapes and is shaped by the perception of the things being symbolised (Appadurai 1988: 38; Knappett 2005: 119). For an example of this principle, we can return to the example of Chinoiserie. At this time, wealthy households in Europe had access both to imported items and also to items made in recognisably foreign styles from both Africa and Asia. However, such households rarely chose to use these 'foreign' items in the same way. Chinoiserie products, such as the blue and white ceramics inspired by the Chinese Kangxi school of ceramics, for example, were extremely popular as formal dining wares for special occasions within domestic contexts. Such oriental-inspired ceramics became both familiar and socially acceptable, whilst still retaining a sense of the exotic - they became socially desirable (Pierson 2007). In contrast, African styles of ceramics enjoyed no such widespread popularity. Instead, they were viewed almost exclusively as curios and museum pieces, suitable for specialist interest but not for practical use, and certainly not suitable for use in 'polite' society (Coombes 1994). The choice to embrace Asian styles of material culture but not African styles is telling. It is indicative of contemporary attitudes to the two continents, illustrating the deeply held prejudices of the time which characterised East Asia as a place of exotic high culture and Africa as a place of barbarism and 
backwardness. Crucially, it is clear that the differentiated way that Asian-style and African-style objects were treated tells us something about the way people viewed the continents of Asia and Africa themselves.

The presence of external influences in material culture can therefore tell us about a site's external contacts, but it is the way these influences were used in different social situations which tells us how people at that site viewed these external contacts. In particular, the use of recognisably 'foreign' objects in socially-charged contexts or important public occasions is especially important. Situations of a public or semi-public nature, with elements of ritual behaviour and conscious social display, are often charged with a high level of social significance. Such situations have long been recognised as important arenas for making social statements and negotiating social identities. Examples of this include the 'ceremonial events' of the Maya élite (DeMarrais et al. 1996: 17-18), as well as ethnographic cases like the days 'when one's heart soars' amongst the Kalahari San (Wiessner 1984: 200). In addition to such comparisons and exempla, the significance of such events has also been highlighted by contemporary signalling theory (Bliege Bird, Alden Smith 2005). The decision to employ a recognisably 'foreign' item in a public or socially-significant setting is therefore always meaningful. While it has long been established that material culture informs social experience (see above), the choice to use such items in these contexts goes beyond social practice and performativity. It is a deliberate statement and a conscious act of representation, and is, therefore, both directly constructive as well as indicative of how this external contact was perceived.

The main bulk of this paper will focus on identifying the various symbols of external Others in the Beycesultan assemblage and analysing how these symbols were deployed and used by the people of Beycesultan, rather than on establishing the extent or nature of contacts between Beycesultan and its neighbours. It has already been noted that while Hittite influence is not much manifest in western Anatolian material culture, Beycesultan would indeed have had some contacts with the Hittite Empire. The question is, therefore, not what Hittite and Hittite-influenced goods were present at Beycesultan, but rather: how did the people of Beycesultan choose to use these items? This paper will consider evidence for public and socially-significant events at Beycesultan, and examine the deployment of symbols of external Others during these events. In particular, it will focus on two types of social occasion for which evidence has been found at Beycesultan and which would have been likely arenas for social display cult activity and communal dining. Both of these activ- ities are common areas of archaeological enquiry and both are widely thought to be imbued with social meaning (Renfrew 1994; Bell, Valentine 1997; Rappaport 1999; Dietler, Hayden 2001). However, it should not be assumed that all cult or group dining activities were necessarily invested with a high degree of social significance. Instead, each instance of either commensality or cult activity identified at Beycesultan will be considered individually to assess whether it can be designated as a socially-charged event or not.

Once relevant events or settings have been identified, the objects and material culture styles used during these occasions will be discussed, with special attention paid to objects and material culture styles which would have evoked a recognisable central or western Anatolian aesthetic. The deliberate choice to use such objects in a socially-charged setting such as cult practice or feasting would have been a meaningful one, and would suggest some level of conscious engagement by people at Beycesultan. In communal dining or feasting events, the primary class of object which will be considered will necessarily be ceramic vessels (serving, drinking or pouring vessels in particular). In cult activity, the objects of analysis will include a much wider range of material, from ceramic vessels to specific architectural forms and assorted small finds.

\section{Hittites and Arzawans: the view from Beycesultan}

As mentioned above, Beycesultan is one of the few excavated sites in the immediate region, and was located in a prominent position between central and western Anatolia. Guarding a corridor between Hatti and Arzawa, the settlement at Beycesultan must have stood poised between these two (apparently hostile) blocs, with trade and diplomatic connections stretching in both directions. The site itself lies over twin höyük mounds, and excavations in the 1950s uncovered parts of both mounds, as well as opening some exploratory trenches on the slopes and around the base (fig. 2; Lloyd, Mellaart $1955 ; 1956 ; 1957 ; 1958 ; 1962 ; 1965$; Lloyd 1972; Mellaart, Murray 1995). The twin mounds both seem to have been given over to domestic architecture, whilst shrine buildings were uncovered in a trench slightly to the north of the mounds, referred to as 'Area R' (fig. 3).

The main Late Bronze Age phase at Beycesultan is level III (ca. 1350-1250 BC; absolute dating of the Beycesultan levels is still vague, and dates given are only rough guidelines) (fig. 4). At this time, the settlement plan seems to have been carefully organised and laid out around two parallel main streets, with several architectural elements respecting the alignments of previous Middle Bronze Age buildings and a new settlement wall being built around the edge of the mounds (Lloyd 1972: 


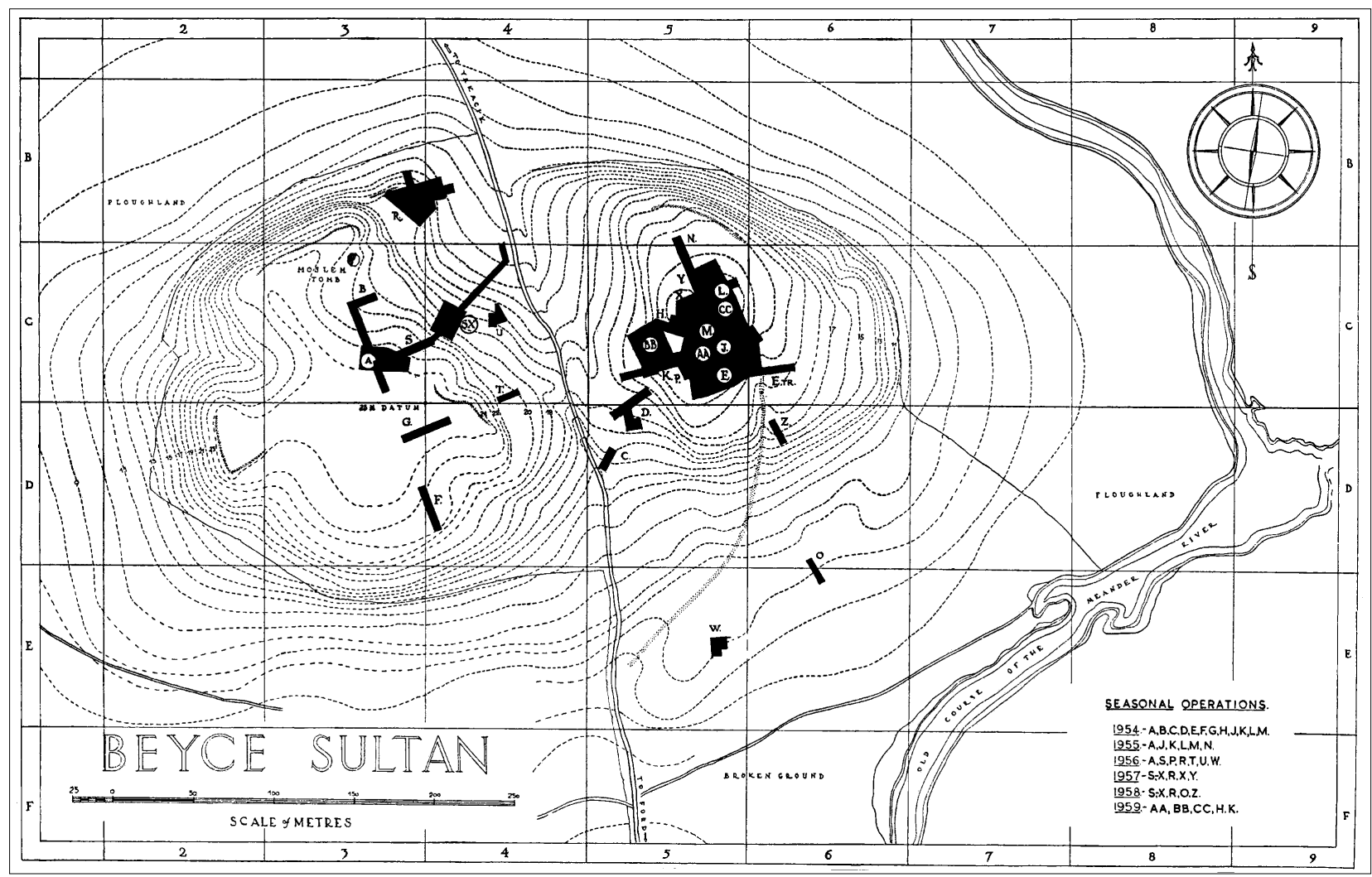

Fig 2. Plan of the 1954-1957 excavations at Beycesultan (reproduced with the kind permission of the British Institute at Ankara)

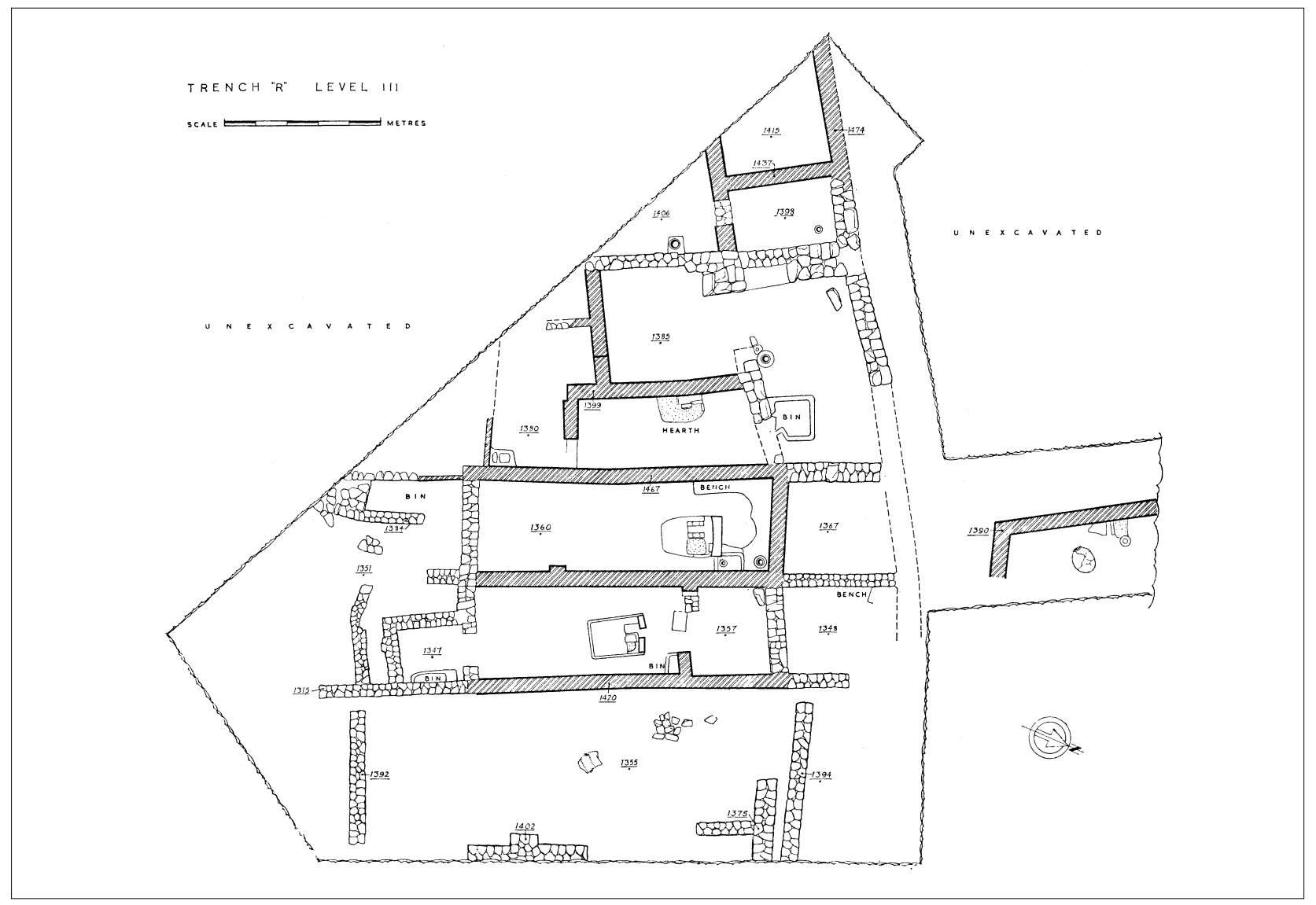

Fig 3. Plan of the shrine buildings in Area $R$ (reproduced with the kind permission of the British Institute at Ankara) 


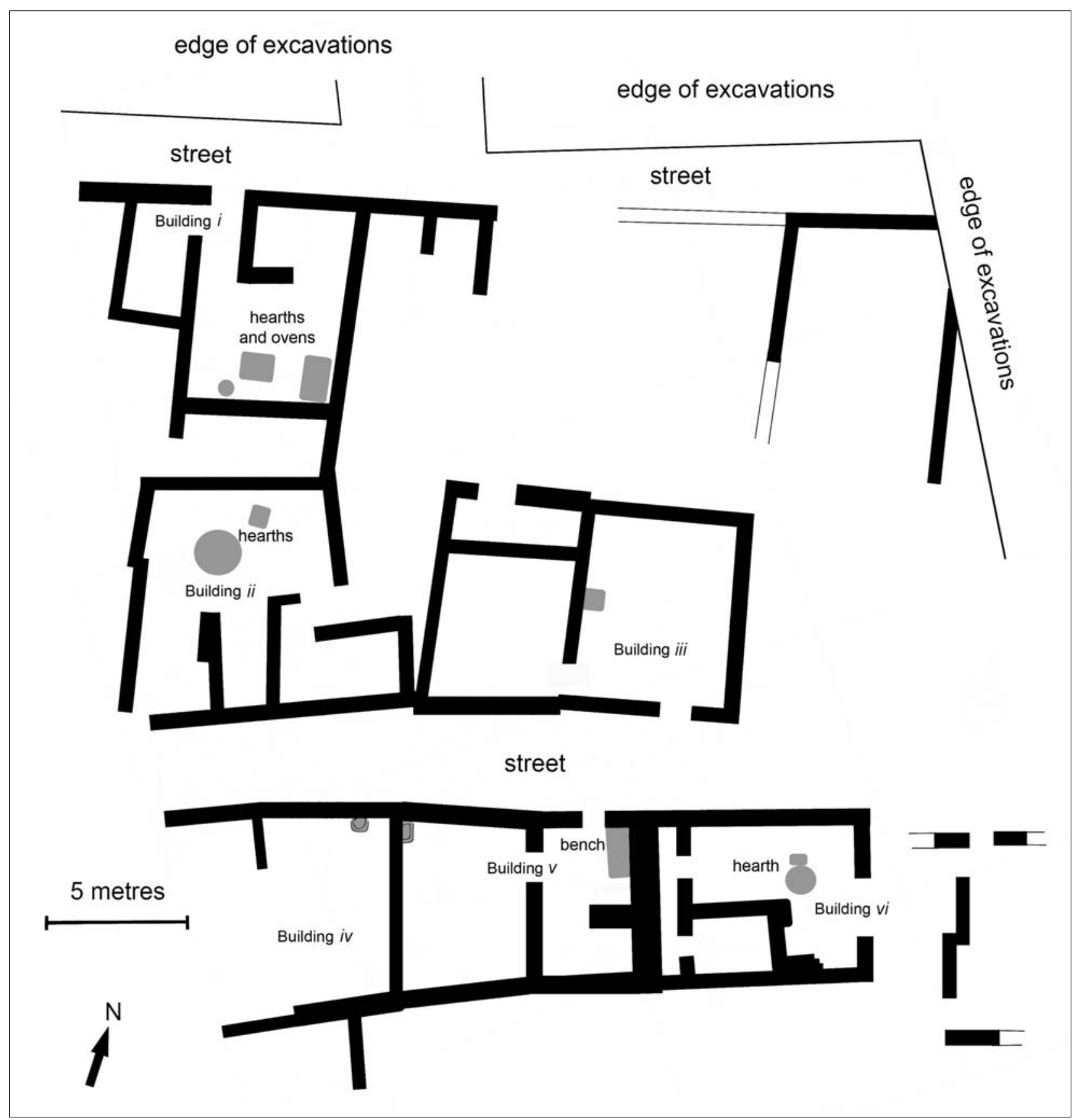

Fig 4. Plan of level III on the east mound of Beycesultan (adapted from Lloyd 1972: fig. 2)

7-9; Mellaart, Murray 1995: 1-2). The houses on the summit of the mounds seem to be well built, made of mud-brick on stone foundations, and tend to consist of several connected rooms opening onto the street. The site's original excavators noted the high standards of architectural construction, evidence for social organisation in town planning and the building of settlement walls, and the presence of valuable élite goods. Such signs of material prosperity and centralisation were considered to be surprising in a period when western Anatolia is assumed to have been in conflict and unstable (Lloyd 1972: 7-9). It is significant that at the peak of
Hittite imperial power, and throughout the Arzawa episode, the settlement at Beycesultan seems to have enjoyed a certain amount of stability, prosperity and continuity with the past.

\section{Representing external contacts at Beycesultan}

Evidence for public, socially-significant events at level III Beycesultan comes both in the form of cult activity and feasting. The cult complex in Area R consisted of two twin-shrine chambers, both entered by a single anteroom to the south (Lloyd 1975: 24-27). The complex lay directly on top of an earlier Middle Bronze 
Age cult building and followed exactly the same lines as its predecessor. The two shrines each contained a hearth/altar installation at their northern ends, both of which are reminiscent of earlier installations found on the site. The altar in the west shrine was particularly traditional, as it featured two terracotta 'horns' stamped with circular designs. The facts that the shrine buildings were constructed on the exact plan of earlier cult installations and that the traditional 'horned' altar was used both point to a high degree of continuity in Beycesultan's cult practice. In this context, the choice to use a recognisably foreign item during a cult activity would have been highly significant.

Commensality seems also to have been an important social practice in level III Beycesultan. Not only do fineware dining vessels constitute a substantial proportion of the overall ceramic assemblage, but the majority of the dining shapes were found in two specific locations - within Buildings $i i i$ and $i v$, both well-built houses on the summit of the east mound (fig 4; table 1). In addition, it should be noted that within two other buildings no dining finewares were found at all, heightening the spatial specificity of this social practice (Buildings $v$ and $v i$; table 1). This concentration of dining vessels in two discrete clusters suggests that commensality was indeed practised in Late Bronze Age Beycesultan, and that these group meals would have been socially-charged occasions where the use of foreign styles would have been meaningful. In level III Beycesultan then, both cult activity and communal dining are likely to have been socially-charged settings where the deployment of a 'foreign' article would have been especially potent.

Opportunities to acquire imported artefacts or to copy foreign styles were plentiful. There is evidence that Beycesultan had a wide network of external contacts during this time; and the presence of exotic, high-status goods such as precious stones, stone vessels and metals suggest its involvement in long-distance trade (Lloyd 1972; Mellaart, Murray 1995). Contact with central Anatolia and the Hittite sphere more specifically is suggested by the appearance of several crescent-shaped objects with pierced ends, usually thought to be loomweights (Mellaart, Murray 1995: 118). While these objects are found at Beycesultan levels III and II, they appear earlier and in greater quantities on the Anatolian plateau (VogelsangEastwood 1990: 97). The advent of this new form of craft object during level III occupation implies that there was contact with central Anatolia at this time; contact which may not have been limited to the trade of objects and commodities, but may also have included the exchange of technologies and craftworking expertise. In addition, the non-dining ceramic assemblage includes a few examples of typically central Anatolian shapes from the Middle Bronze Age onwards,

\begin{tabular}{|c|c|c|c|}
\hline \multirow{4}{*}{ Level III buildings } & Number of vessels & \% of vessels \\
\cline { 2 - 4 } & Building $i$ & 2 & 1.8 \\
\cline { 2 - 4 } & Building $i i$ & 1 & 0.9 \\
\cline { 2 - 4 } & Building iii & 28 & 25.2 \\
\cline { 2 - 4 } & Building $i v$ & 48 & 43.2 \\
\cline { 2 - 4 } & Building $v$ & 0 & 0 \\
\cline { 2 - 4 } & Building $v i$ & 0 & 0 \\
\hline \multirow{4}{*}{ Level II buildings } & Total & $\mathbf{1 1 1}$ & 28.8 \\
\cline { 2 - 4 } & Bussociated with any building & 15 & $\mathbf{9 9 . 9 0 \%}$ \\
\cline { 2 - 4 } & Building viii & 25 & 9.4 \\
\cline { 2 - 4 } & Building $i x$ & 39 & 15.8 \\
\cline { 2 - 4 } & Building $x$ & 22 & 24.7 \\
\cline { 2 - 4 } & Buildings $x i$ and $x i i$ & 37 & 13.9 \\
\cline { 2 - 4 } & Not associated with any building & 20 & 23.4 \\
\cline { 2 - 4 } & & $\mathbf{1 5 8}$ & $\mathbf{9 9 . 9 0 \%}$ \\
\hline
\end{tabular}

Table 1. Quantities of fineware dining vessels by excavated structure 


\begin{tabular}{|c|c|c|c|c|c|c|c|c|c|}
\hline \multicolumn{2}{|c|}{} & A1 & A2 & B & C1 & C2 & D & X & Total \\
\hline \multirow{2}{*}{ Level III } & Number & 4 & 15 & - & 62 & 22 & - & 8 & $\mathbf{1 1 1}$ \\
\cline { 2 - 11 } & $\%$ & 3.6 & 13.5 & - & 55.8 & 19.8 & - & 7.2 & $\mathbf{9 9 . 9 0 \%}$ \\
\hline \multirow{2}{*}{ Level II } & Number & 13 & 46 & 1 & 46 & 23 & 7 & 22 & $\mathbf{1 5 8}$ \\
\cline { 2 - 11 } & $\%$ & 8.2 & 29.1 & 0.6 & 29.1 & 14.6 & 4.4 & 13.9 & $\mathbf{9 9 . 9 0 \%}$ \\
\hline
\end{tabular}

Table 2. Fineware dining vessels by decorative type. A1: silver and gold lustrous slipped wares (Hermos river valley area); A2: coppery-red lustrous slipped wares (Upper Maeander adaptation of A1); B: linear painted decoration on a lustrous surface (Lower Maeander adaptation of A1); C1: warm-coloured burnished wares (Upper Maeander river valley area); C2: warm-coloured slipped wares (no clear regional connection); D: grey and black wares (northwest Anatolia and the Troad); X: other or unknown decoration

suggesting a long-standing 'acquaintance' with Hittite pottery traditions (Gunter 2006: 355). Contacts with the west are also evident. A Mycenaean stirrup jar, found built into the walls of a level III building, suggests that Beycesultan did have some trading connections westwards, stretching across the Arzawa lands to the Aegean (Mellaart, Murrary 1995: 2, 93). In addition, the small quantities of Hermos valley lustrous wares in the ceramic assemblage (table 2) also indicate some level of contact with communities further west. People at Beycesultan therefore did have contacts with both the Hittite and Arzawan core areas, and could have chosen to adopt, adapt or imitate their visual styles if they had wished to do so.

Despite this, the population seems to have had relatively little interest in using any foreign or foreignstyle items during socially-charged events. It is significant that none of the items which can be connected to a specific external location was found inside the shrines in Area R. Instead, this symbolic space seems to have been reserved exclusively for items bearing explicitly local associations or items which carried no overt geographical associations at all, such as metal tools made in a generic style (see below).

The assemblage of dining vessels from this period also illustrates this tendency clearly. Out of the 111 fineware dining vessels recorded for this phase, over half of them (62 vessels or $55.8 \%$ ) can be categorised as belonging to the same decorative scheme (Type $\mathrm{C} 1$; table 2). Vessels of Type $\mathrm{C} 1$ are highly distinctive and instantly recognisable; they have a highly burnished surface, often with pattern burnishing, and appear in a narrow range of colours ranging from warm brown through to red and deep orange (fig. 5). Such decoration is closely associated with Beycesultan and the Upper Maeander area during the Middle and Late Bronze Ages, and can be thought of as being a distinctly local ware with expressly local connotations (Mellaart, Murray 1995: 1-2). The popularity of Type
$\mathrm{C} 1$ vessels is indeed remarkable - not only do they dominate the dining assemblage for this phase, but level III also shows a much higher degree of ceramic standardisation than any other phase at Late Bronze Age to Early Iron Age Beycesultan (Mac Sweeney 2009: table 3).

In addition to the Type $\mathrm{C} 1$ vessels, the assemblage also features a significant number of Type A2 wares - a hybrid style which is based on the local Upper Maeander C1 wares (see above), but which incorporates the lustrous surface finish better known from Type A1 Hermos valley lustrous wares (Mellaart, Murray 1995: 105-06). Taking Types $\mathrm{C} 1$ and $\mathrm{A} 2$ together then, a total of 77 vessels $(69.3 \%)$ can be said to recall specifically local associations through their decorative scheme. In addition to this, analysis of vessel shape also shows a preference for local styles (table 3; figs 5 and 6), with the assemblage comprising 72 vessels (64.9\%) in characteristic Upper Maeander shapes.

This emphasis on local styles in terms of both shape and decorative scheme is significant, and stands in contrast to the relatively small proportion of the assem-

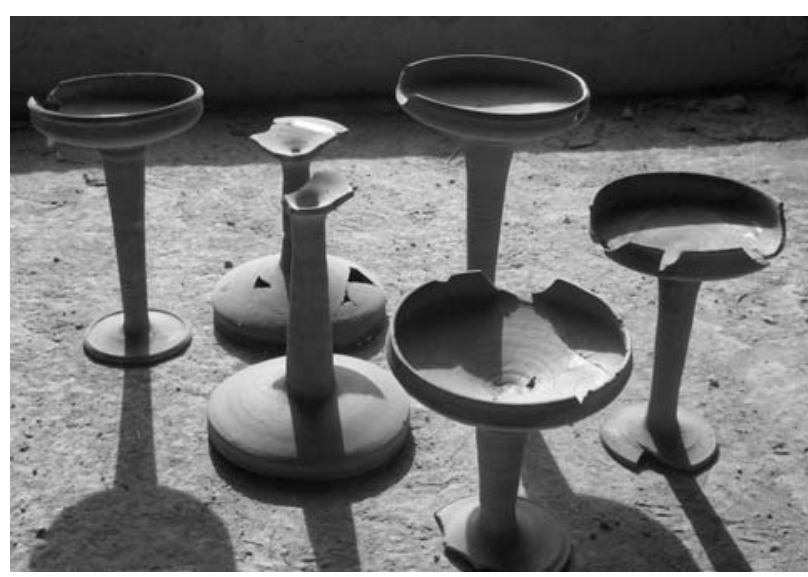

Fig 5. Chalices of Type C1 decoration from level III Beycesultan 


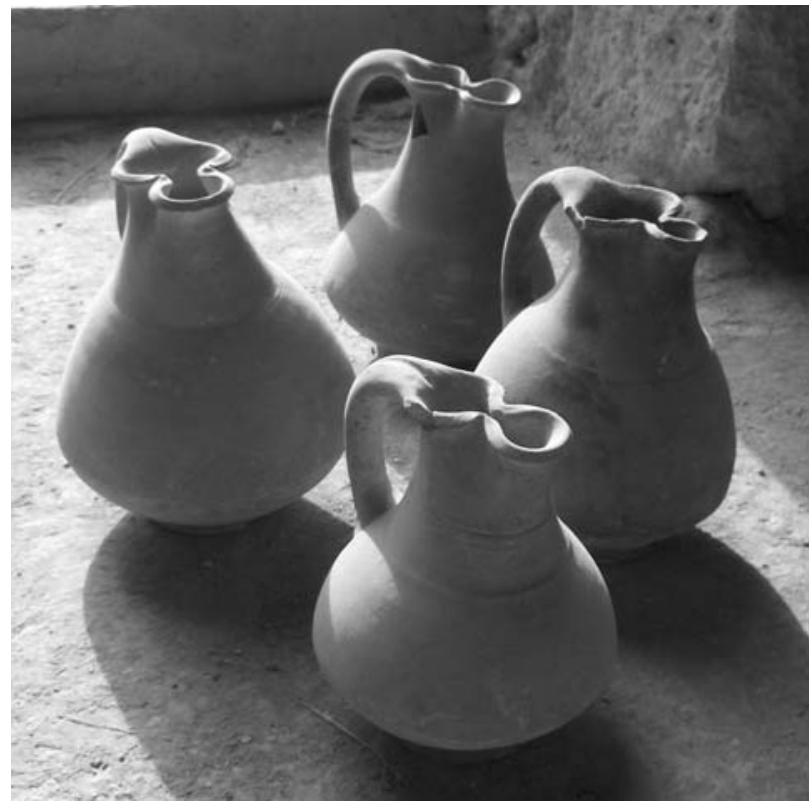

Fig 6. Bifoil jugs of Type C1 decoration from level III Beycesultan

blage which recalls non-local associations. Only four vessels evoke a foreign style in their decoration - all belonging to Type A1, reminiscent of the Hermos region. Of these, three are characteristically Upper Maeander shapes (chalice and fruitstand), while the fourth is a simple bowl with no particular geographic connotations. No other vessels appear to evoke any specific foreign styles through their decorative scheme. As mentioned above, characteristically central Anatolian shapes are known at level III Beycesultan, but it is significant that these comprise a relatively modest proportion of the socially-charged dining assemblage (13.5\%). In addition, these vessels do not represent the entirety of the typical Hittite dining assemblage, familiar across much of central and southeastern Anatolia (Hawkins 1995b; Gates 2001; Gunter 2006). Instead, they are narrowly limited to beaked jugs and plates; shapes with a long previous history at Beycesultan and which the population may not have considered to be characteristically 'Hittite'. Finally, it should also be noted that the majority of these vessels belong to the local Types $\mathrm{C} 1$ or A2 in terms of decoration, with only two plates decorated in the more generic Type C2. Overall therefore, the fineware dining assemblage seems to be dominated by local styles in terms of both decoration and shape. While people at Beycesultan certainly do seem to have been aware of non-local styles, including both central Anatolian and western styles, it seems that they did not often choose to use them in the sociallysignificant sphere of feasting. This must be in some way meaningful.

A similar impression can be gained from the objects found within the shrines (table 4). It is notable that most of the items within this highly-charged and fiercely traditional space would probably have borne specifically local connotations. The three ceramic vessels found in the shrines all belong to local styles, and the other objects found in the shrines were all types which are attested at Beycesultan during earlier periods. The two anthropomorphic marble figurines are examples of this, as both of them are familiar types from the Beycesultan Middle Bronze Age shrine buildings (Mellaart, Murray 1995: 122). It is also significant that one of these figurines (the violin-shaped figurine) is also a type which is closely associated with the wider local area of inland southwestern Anatolia, as examples have been found at the nearby sites of Kusura (Lamb 1936: 29) and Aphrodisias (Joukowsky 1986: 220).

\begin{tabular}{|c|c|c|c|c|c|c|}
\hline \multicolumn{2}{|c|}{} & $\begin{array}{c}\text { Characteristically } \\
\text { local Upper } \\
\text { Maeander shapes }\end{array}$ & $\begin{array}{c}\text { Characteristically } \\
\text { central Anatolian } \\
\text { shapes }\end{array}$ & $\begin{array}{c}\text { Characteristically } \\
\text { Aegean / western } \\
\text { shapes }\end{array}$ & $\begin{array}{c}\text { Shapes not } \\
\text { characteristic of } \\
\text { any region }\end{array}$ & Total \\
\hline \multirow{2}{*}{ Level III } & Number & 72 & 15 & - & 24 & $\mathbf{1 1 1}$ \\
\cline { 2 - 8 } & $\%$ & 64.9 & 13.5 & - & 21.6 & $\mathbf{1 0 0 \%}$ \\
\hline \multirow{2}{*}{ Level II } & Number & 90 & 21 & 9 & 38 & $\mathbf{1 5 8}$ \\
\cline { 2 - 8 } & $\%$ & 56.9 & 13.3 & 5.7 & $\mathbf{1 0 0 \%}$ \\
\hline
\end{tabular}

Table 3. Fineware dining vessels by shapes. Characteristically local Upper Maeander shapes at Beycesultan levels III-II: Chalice, fruitstand, carinated bowl, quatrefoil cup, mug, 'teapot', 'feeding bottle'; characteristically central Anatolian shapes at Beycesultan levels III-II: bowl with curved base, beaked jug, dish/plate; characteristically Aegean/western shapes at Beycesultan levels III-II: krater; shapes not characteristic of any region at Beycesultan levels III-II: plain bowls with ring or flat base, plain jug, bifoil and trefoil jugs 


\begin{tabular}{|c|c|c|c|c|}
\hline \multirow{18}{*}{$\begin{array}{c}\text { Level } \\
\text { III }\end{array}$} & Object & Description & Material/Type & Reference \\
\hline & Beaked jug & Red-brown pattern burnished, fine buff ware & Type C1 & (P6.5) \\
\hline & Fruitstand & Red lustrous, fine buff ware & Type C1 & $\mathrm{BS} / 57 / 777$ (P1.24) \\
\hline & Askos & Raised decoration, buff ware & Type F & $\mathrm{BS} / 57 / 845$ \\
\hline & Pin & Melon-shaped head & Bronze & $\mathrm{BS} / 57 / 829$ \\
\hline & Pin & Broken roll head & Bronze & BS/57/796 (M55) \\
\hline & Chisel & Socketed, with square section and blade & Bronze & $\mathrm{BS} / 57 / 844$ (M71) \\
\hline & Ring & Plain, circular & Silver & $\mathrm{BS} / 57 / 852(\mathrm{M} 81)$ \\
\hline & Ring & Plain, circular & Silver & $\mathrm{BS} / 57 / 851(\mathrm{M} 78)$ \\
\hline & Figurine & Flat figurine with a stalk neck and semicircular body & Marble & $\mathrm{BS} / 57 / 775 \mathrm{a}(\mathrm{M} 258)$ \\
\hline & Figurine & Flat figurine of type common in Early Bronze Age levels & Marble & $\mathrm{BS} / 57 / 775 \mathrm{~b}(\mathrm{M} 258)$ \\
\hline & Dagger pommel & Shafting and riveting holes & Marble & $\mathrm{BS} / 57 / 750$ \\
\hline & Mould for tools & Mould for making blades and a chisel & Limestone & BS/57/807 (M257) \\
\hline & Macehead & & Stone & $\mathrm{BS} / 57 / 769$ \\
\hline & Loomweight & Crescent-shaped, perforations, three stamp decorations & Orange clay & BS/57/757 (M170) \\
\hline & Spindle whorl & Truncated conical shape, with white-filled incised decoration & Black clay & $\mathrm{BS} / 57 / 735$ (M168) \\
\hline & Stamp seal & $\begin{array}{l}\text { Stamp seal with concentric circles design, for stamping on } \\
\text { clay horned altars }\end{array}$ & Clay & $\mathrm{BS} / 57 / 751(\mathrm{M} 171)$ \\
\hline & Knife handle & Gently curved & Horn & BS/57/730 (M306) \\
\hline \multirow{20}{*}{$\begin{array}{l}\text { Level } \\
\text { II }\end{array}$} & Carinated bowl & Red lustrous, pattern burnish & Type A2 & $\mathrm{BS} / 57 / 754$ \\
\hline & Fruitstand & Red lustrous, grooved decoration & Type A2 & $\mathrm{BS} / 57 / 774$ \\
\hline & Fruitstand & Red lustrous & Type A2 & (P14.7) \\
\hline & Jug & Red lustrous & Type A2 & $\mathrm{BS} / 57 / 756$ \\
\hline & Jug & Red-painted stripe & Type B2 & $\mathrm{BS} / 57 / 755$ \\
\hline & Chalice & Black and silver slipper, buff ware & Type D & $\mathrm{BS} / 57 / 771$ \\
\hline & Fruitstand & Light-grey slip & Type D & $\mathrm{BS} / 57 / 748$ \\
\hline & Chalice & Spiral incised decoration on stem, buff ware & Type D & $\mathrm{BS} / 57 / 772$ \\
\hline & Dagger blade & Shafting hold and raised ridges at either edge & Bronze & $\mathrm{BS} / 57 / 724$ \\
\hline & Arrowhead & Leaf-shaped, with round mid-rib and tang & Bronze & $\mathrm{BS} / 57 / 825$ \\
\hline & Arrowhead & Leaf-shaped, with pronounced mid-rib and tang & Bronze & $\mathrm{BS} / 57 / 824$ \\
\hline & Spearhead & Socketed & Bronze & $\mathrm{BS} / 57 / 810$ \\
\hline & Awl & Rectangular section, tapering in centre & Bronze & BS/58/863 (M96) \\
\hline & Awl & & Bronze & BS/57/768 (M318) \\
\hline & Shell necklace & Necklace of 244 cowrie shells, knucklebones, carnelian bead & Shell, bone, stone & BS/57/776 (M338) \\
\hline & Shell necklace & Necklace of 46 cowrie shells & Shell & BS/57/831 (M339) \\
\hline & Frit necklace & Necklace of 17 frit beads & Frit & BS/57/830 (M244) \\
\hline & Shoe figurine & With incisions in imitation of stitching & Buff clay & BS/57/717 (M203) \\
\hline & Bone tube & Carved tube, with finely incised decoration & Bone & $\mathrm{BS} / 57 / 757$ (M324) \\
\hline & Bone tube & Carved tube, with finely incised decoration & Bone & BS/57/743 (M325) \\
\hline
\end{tabular}

Table 4. Objects and ceramic vessels found in the shrine buildings in Area R. Reference numbers are those used in the original register book of finds. The numbers in brackets are those used by Mellaart and Murray in their publication of finds and pottery from the site (Mellaart, Murrary 1995) 


\section{Perceptions of external contacts at Beycesultan}

This preference for distinctly local styles in sociallycharged settings seems to be significant, especially given the wider historical context. Level III was roughly contemporary with the peak period of the Arzawan confederacy and its disbandment by Mursili II (ca. 1325 BC), and also the period of Hittite political involvement in western Anatolia which followed. As already discussed, Beycesultan during this time was exposed to Hittite cultural influences and had access to central Anatolian trade routes and commodities. Despite this contact and communication, however, people here do not seem to have incorporated central Anatolian influences or styles into their socially-charged events and practices. Most notably, the Hittite language of power - the artistic motifs, visual styles and cult practices which were adopted so enthusiastically by other areas on the Hittite periphery (Hawkins 1995b; Gates 2001; Gunter 2006) is conspicuously absent at Beycesultan (see above). This may have been a local response to the hostility that must have existed between western Anatolian groups and their bellicose eastern neighbours. In any case, Hittite influence at Beycesultan may be interpreted not so much as absent, but as deliberately avoided. The Hittite claim to dominance here in Kuwaliya seems to be something of an exaggeration.

More surprising, however, is that there are no obvious signs that people at Beycesultan were eager to embrace styles or influences from other western Anatolian groups. From what we know of the Arzawan confederacy, contacts between the various western Anatolian groups must have been relatively regular and communication was probably frequent. The remains from Beycesultan itself broadly support this, as imports from the west have been found in this level (see above; Mellaart, Murray 1995: 2).

During a time when Beycesultan was probably linked to groups across western Anatolia in a political alliance, the lack of any obvious symbols of Arzawan solidarity is significant and raises questions concerning the strength and importance of the confederacy itself. Was Arzawa really a strong and threatening alliance whose defeat brought Mursili great glory? Was it only a temporary association, cobbled together for political expediency rather than being an alliance based on stronger social or cultural ties? Indeed, was it really a difficult feat for Mursili to divide Arzawa into three separate kingdoms?

We should bear in mind that the Hittite documents were composed as stylised works of imperial rhetoric, and perhaps should not be taken completely at face value as historical records (Güterbock 1983). While the archaeological and linguistic evidence argues against any sort of cultural unity across western Anatolia (see above), the material from Beycesultan also seems to oppose specifically the idea of a conscious unity or identity.

In level III Beycesultan, a deliberate choice was made to eschew both central Anatolian and western styles of material culture during socially-charged public events. It is perhaps significant that there does not seem to be any central 'palace' or focal administrative structure at Beycesultan. Unlike many contemporary settlements, the site lacks a central focus for political power or administrative control. While the presence of high-value exotic goods suggests that there was social differentiation and an interest in élite status at the site (see above), this élite status appears to be less institutionalised and perhaps more flexible than in other comparable settlements. In this context, it should be noted that feasting activities are likely to have happened at two different locations in two separate buildings rather than in one central structure. Given this apparent lack of rigidity in the social structure of level III Beycesultan, it seems somewhat unlikely that the decision to exclude external influences was imposed unilaterally in accordance with some kind of 'official line'. Instead, this is a choice which must have been accorded some level of acceptance or support from the participating population. While a full discussion of group dynamics and collective identity at Beycesultan is beyond the remit of this paper, it appears that the preference for local over both eastern and western styles was one which resonated, to at least some extent, with the wider Beycesultan community.

Given our knowledge of the historical circumstances, we might be tempted to see this period in western Anatolia in terms of 'Hittites vs. Arzawans'. However, the evidence from Beycesultan warns against adopting such a view. For people here during the Late Bronze Age, there appears to have been no compulsion to be drawn either to the east or to the west - instead, at socially-significant occasions, there seems to have been a strong emphasis placed on local tradition and indigenous styles. Interpreting this local focus at Beycesultan is not easy. It implies a certain comparable attitude to both Hittites and the other members of the Arzawan confederacy - were both groups equally unappealing at Beycesultan, equally uninteresting or equally threatening? Sandwiched between two hostile blocs, did Beycesultan deliberately portray itself as neutral, strategically positioning itself as associated with neither? It is impossible to answer such questions with any certainty. Asking such questions, however, is worthwhile in itself. It encourages us to interrogate the Hittite sources more closely, and warns against the assumption that groups on the imperial periphery were necessarily preoccupied with their interactions with Hatti. 


\section{Postscript: after Hittites and Arzawans}

From this brief discussion of Late Bronze Age Beycesultan, it seems that attitudes in western Anatolia to Hittites and other members of the Arzawan confederacy may not have been as straightforward as might have been thought originally. Being on the imperial periphery did not necessarily mean being peripheral, and groups in places such as Beycesultan may not necessarily have thought of themselves as languishing on the margins. For these people, the Hittites were only one of several neighbours, and perhaps not even a neighbour accorded much in the way of special treatment. At Beycesultan, the evidence seems to be mostly negative - the settlement does not seem to have looked to central Anatolia, but equally it seems not to have looked to the west. Could this, however, be a result of Hittite influence itself? Could this be a consequence of Mursili's forcible dispersal of the Arzawan confederacy? The apparent disinterest in western styles at the peak of the confederacy period does not support this interpretation. It also seems unlikely given the choices made by the people of Beycesultan after Hittite power had declined, during the Late Bronze Age to Early Iron Age transition.

This transition at Beycesultan can be seen in level II (ca. 1250-1150; fig. 7). The transitional phase would have been broadly contemporary with the decline and shrinking of the Hittite Empire and the first few decades after Hatti lost its imperial territories (Bryce 1999: 340;

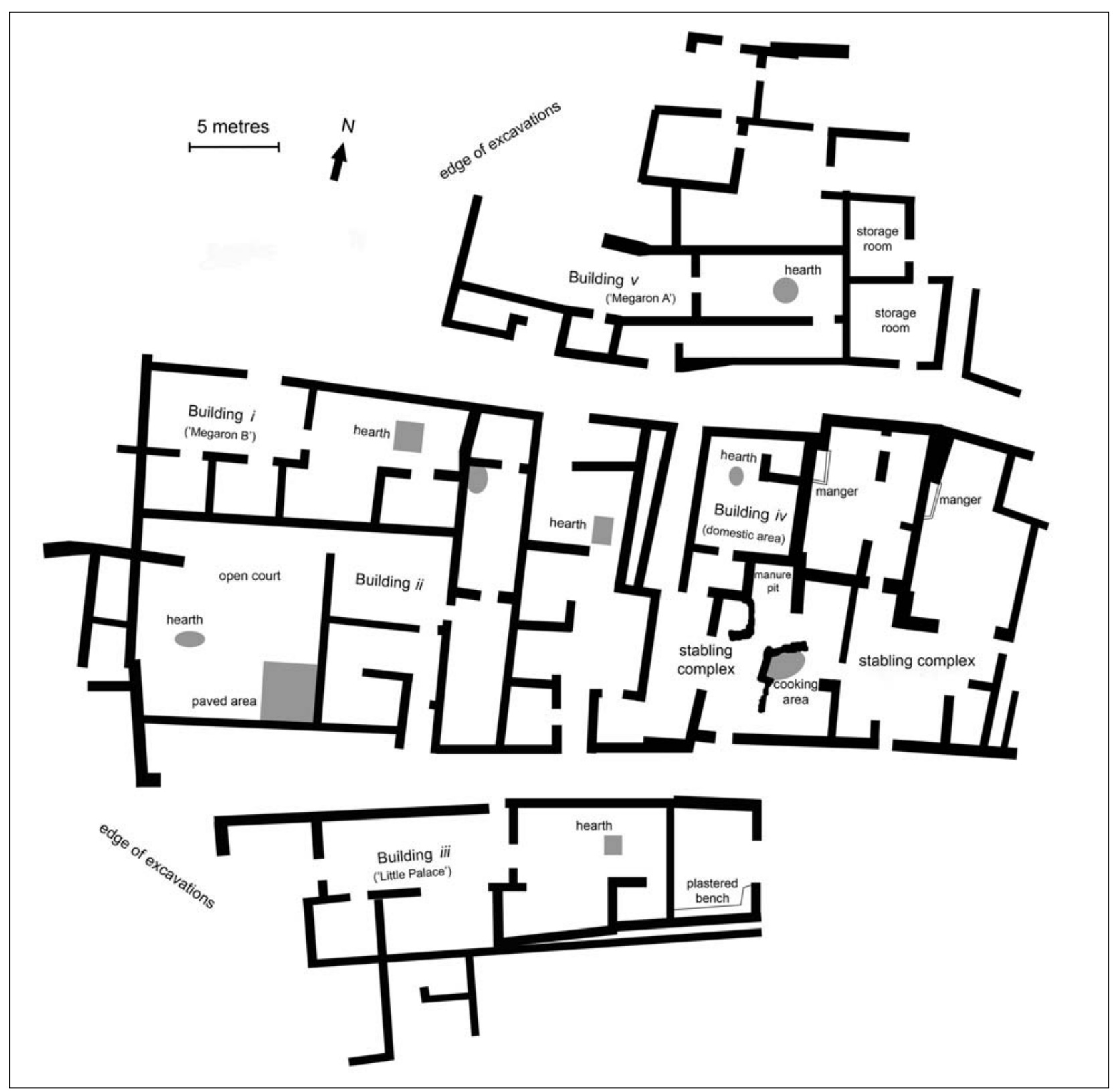

Fig 7. Plan of level II on the east mound of Beycesultan (adapted from Lloyd 1972: fig. 3) 
Schoop 2003; 2006b). There are signs that feasting was perhaps slightly less important during this phase than in the previous level, as fineware dining vessels were distributed more evenly across the site (table 1). Although there do seem to be some locations where vessels were clustered, no cluster from this phase is as large (either in terms of absolute numbers or proportion of overall assemblage) as the main feasting cluster from level III. While it could be argued that feasting did not decline, but was instead more accessible and carried out in a wider range of locations, the overall character of the remains does not support this. I have argued elsewhere that level II sees a greater centralisation of resources and increasing rigidity in the social hierarchy of Beycesultan (Mac Sweeney 2009). In this context, it seems unlikely that feasting became more widely accessible. Instead, communal dining seems to have been carried out on a more modest scale. Therefore, while communal dining still seems to have been practised in level II Beycesultan, it may not have been quite as socially charged as it previously had been. In contrast to this, cult activity appears still to have provided a focus for socially-significant occasions and may have even become a more important focus for the population. Whilst the general layout and orientation of the complex was maintained, level II saw major works undertaken at the shrine buildings (Lloyd 1972: 27-32). While communal dining may have been a slightly less important source of socially-significant occasions than before, cult practice might perhaps have filled this gap at least partially.

In the socially-charged arena of cult activity, however, it seems that the people of Beycesultan were still loathe to embrace external styles. The objects deposited in the shrines are not obviously reminiscent of any specific foreign style or connection, and most items are of types already familiar at the site (table 4). There is some limited allusion to places beyond the immediate locale, however, in the form of three necklaces. These necklaces were the only items which were not obviously local, as they were made from imported beads and shells and would probably have looked conspicuously exotic. However, it should be noted that these items cannot be linked to any particular provenance and are more likely to have evoked an aura of high status and élite identity rather than connections with a specific external group.

The pottery vessels found in the shrines offer perhaps more of a clue to the representation of external Others. Although a small assemblage, it is nonetheless interesting to note that some of these vessels are likely to have been recognisably 'foreign' to people at Beycesultan. The three grey-ware (Type D) vessels evoke a style familiar from northwest Anatolia and the Troad (Bayne 2000). The other vessels are either styles unconnected to a specific location or Upper Maeander coppery lustrous (Type A2) wares. This rather mixed ceramic assemblage suggests two things. Firstly, that people at Beycesultan did use some recognisably 'foreign' pottery; and, secondly, that, despite this, they still favoured a style which adapted external influences to suit local tastes. In the extremely highly-charged and deeply-conservative space of the shrine buildings, it seem that people were beginning to incorporate selectively external influences and objects, whilst generally preferring local styles of material culture.

As mentioned above, feasting and group dining events during this time may not have been quite as heavily imbued with social significance as previously. Nonetheless, it is worth noting that the impression gained from communal dining is similar to that gained from the socially-charged arena of cult practice. The types of vessels which were used on such occasions include a much broader range of styles than during the earlier level III phase, and no single style dominates the assemblage as Upper Maeander (Type C1) wares did previously (table 2). Like the material from the shrine buildings, the assemblage of fineware dining vessels suggests a new willingness to embrace foreign styles of material culture but within a traditionalist framework. Silver and gold lustrous wares reminiscent of the Hermos valley (Type A1) appear in greater numbers than before, and are used alongside black and grey wares in northwestern styles (Type D) (figs 8 and 9). The appearance of a characteristically western vessel shape in this level, the krater, is perhaps related to this moderate increase in western associations (table 3). From this, it appears that influences from the west and northwest seem to have been selectively embraced. By contrast, there is little change in the use of central Anatolian styles - there is a similar proportion of central Anatolian shapes as before, and, also as before, these are all presented in specifically local or generic decorative schemes. And, as in the previous level III, the familiar Hittite-produced ceramic 'package' is still conspicuously absent.

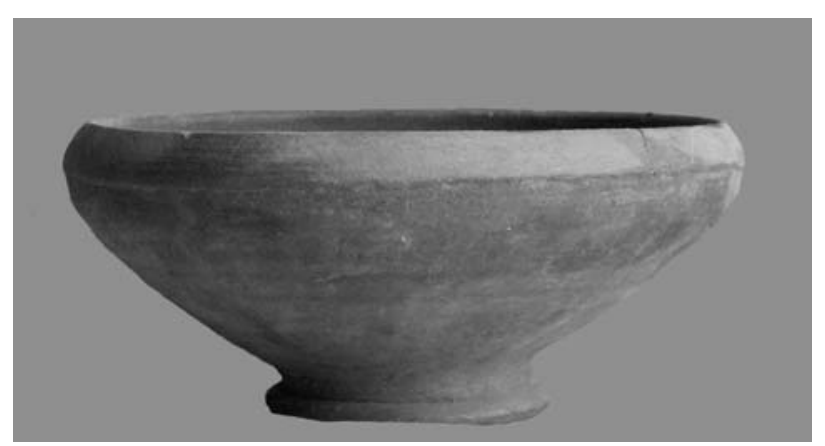

Fig. 8. Bowl of Type D decoration from the shrine buildings of level II Beycesultan 


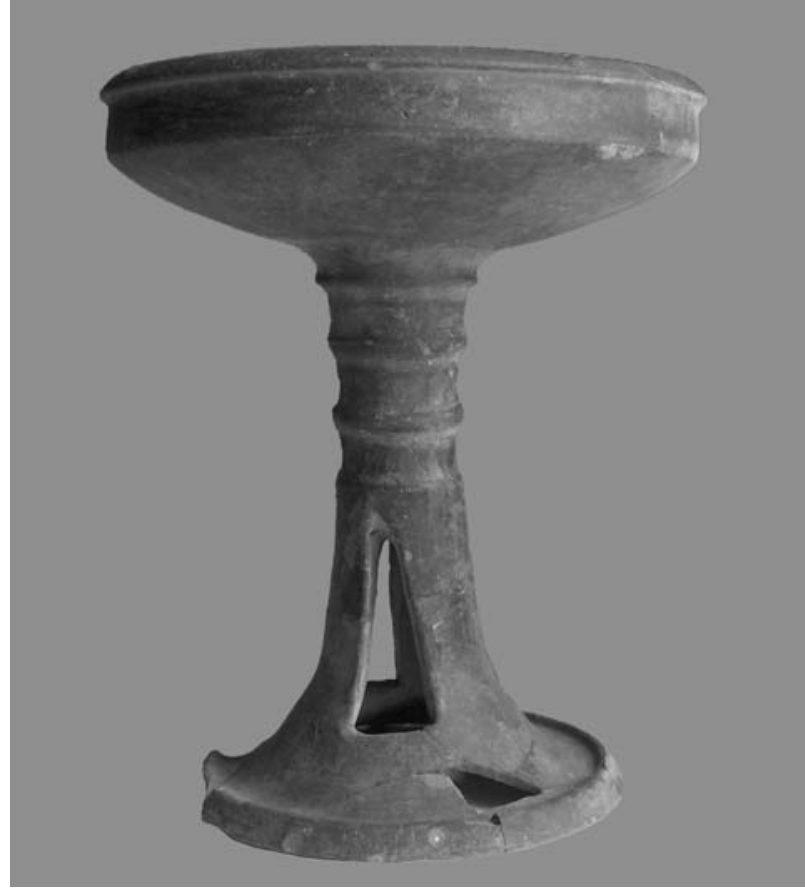

Fig 9. Fruitstand of Type D decoration from the shrine buildings of level II Beycesultan

Alongside this increase in western associations and continued marginalisation of eastern connections, the preference for specifically local styles is still in effect, albeit not quite as strongly as before. It is significant that the local innovation on the Hermos style (Type A2) continued to be substantially more popular than the true Hermos style (Type A1), that the characteristic local Upper Maeander wares (Type C1) remained reasonably popular and that typical Upper Maeander vessel shapes continue to form the largest single shape-group within the assemblage (table 3). Overall, it therefore seems that, while both dining and cultic assemblages both now incorporated some external elements, the overall preference seems still to have focused around local traditions and styles.

Around this time, the power of the Hittite Empire was waning, and Hatti's influence beyond its immediate heartland faded. Tarhuntassa in southern Anatolia and Karkemish in northern Syria, both once client states of the Hittite Great King, became increasingly independent in the final years of the 13th century, with the rulers of both states styling themselves as 'Great Kings' in their own right (Klengel 2002: 109; Mora 2003). David Hawkins has argued that this phenomenon also occurred in western Anatolia, where he sees a political resurgence in the exArzawan principality of Mira (Hawkins 1998; 2002: 150). Anatolian geopolitics had changed dramatically. It is perhaps somewhat surprising, then, that Beycesultan's outlook did not also change dramatically. In socially- significant settings a continued preference for local material culture styles persisted. There is, however, a slight but notable shift. At this time, people at Beycesultan became more willing to incorporate external stylistic elements, implying some change in attitudes and perspectives. In particular, there seems to be a tendency towards adopting styles from western and northwestern Anatolia from either the Troad or the Hermos valley area. This is especially significant given that scholarship has now located the rising kingdom of Mira between the Cayster and Hermos rivers (Hawkins 1998; Collins 2008: 18).

Was Beycesultan well disposed towards its western neighbour, perhaps remembering old alliances now that Mira was prospering? But why should Beycesultan focus on its links to only one of its former Arzawan allies? Did Mursili's division of Arzawa (which linked Mira and Kuwaliya) make use of a deep-held connection between the two areas? Or were the people of Beycesultan more strategic than that, using their political savvy to ingratiate themselves with a neighbour which was growing increasingly powerful? We can only speculate.

\section{Conclusions}

This paper has examined the material culture types that were used by the people of Late Bronze Age to Early Iron Age Beycesultan in socially-charged settings, with a particular view towards forms of material culture which might have been considered to be 'foreign'. It has focused on cult practice and communal dining activities, as these settings were likely to have been invested with social significance and the choice of objects in such instances would have constituted a deliberate and conscious statement. Such statements would have actively constructed social perceptions about 'foreign' contacts, as well as being indicative of them. It has therefore been suggested that something about how people at Beycesultan viewed their external contacts might be gleaned from their choice of material culture in such socially-charged situations. This analysis has been informative, but perhaps it has posed more questions than it has answered. The paper has highlighted that there is a variety of possible interpretations for the material from Beycesultan and it is hoped that in the near future new research will allow us to construct more detailed and more informed interpretations about the site and its people.

In the meantime, however, posing these new questions nonetheless encourages us to view the site in a new light; as a dynamic and unique settlement, with its own social development and political culture. Beycesultan cannot be described by the degree of its Hittiteness or Arzawan-ness, but should instead be understood as independent and not necessarily pulled to one or the other side. During the Late Bronze Age, at the time of the 
Arzawan confederacy and in the wake of Mursili's antiArzawan campaigns, there seems to have been an equal unwillingness to incorporate elements recognisable as either Hittite or Arzawan into Beycesultan's sociallycharged activities. Although it had practical dealings with neighbours on both sides, it appears that Beycesultan preferred to emphasise local Upper Maeander connections during both feasting and cult events. This implies that local identity and local traditions were considered more important, and that people at Beycesultan did not define themselves primarily in terms of their relationship with either the Hittites or the other Arzawan groups.

The material from the Late Bronze Age to Early Iron Age transition suggests that this was an enduring attitude at Beycesultan, and neither a product of Hittite-enforced isolation from the other Arzawan allies nor a side effect of living on the imperial periphery. During and after the decline of Hittite power, local styles and connections remained important at Beycesultan. However, people did selectively begin to incorporate some external influences into socially-charged contexts, but limiting these only to styles recalling Mira in the west and the Troad in the northwest. This subtle shift must relate in some way to the shifting geopolitics of the time and the rise of Mira as a political force in Anatolia.

The many questions raised by this paper also remind us not to make assumptions about the nature of Hittite imperial territories, and not to take the Hittite documents at face value as sources for neighbouring groups. While Hatti may be at the geographical centre of Anatolia, it should not necessarily always be at its disciplinary centre also. We must bear in mind that when studying sites such as Beycesultan the local population may have thought of both Hittites and the Arzawan confederacy as being equally peripheral.

\section{Acknowledgements}

This article makes use of research conducted as part of my $\mathrm{PhD}$ dissertation, and I am very grateful to my supervisor, Robin Osborne, for his guidance and support. I have also benefited from exchanging ideas with (in alphabetical order) Lisa French, Claudia Glatz, David Hawkins, Erim Konakci, Roger Matthews, Sara Owen, Nicholas Postgate, John Robb, Emre Şerifoğlu and Todd Whitelaw. While much credit must go to them, any oversights and mistakes are solely my own. I would also like to thank Gina Coulthard, Gülgün Girdivan and Yaprak Eran of the British Institute at Ankara, Bert Smith and Chris Ratté of the Aphrodisias project, and Huseyn Baysal and Salim Uğulmar of the Denizli Provincial Museum for facilitating primary studies of ceramic material and access to archives. I am also grateful to the anonymous reviewers who have helped to refine and clarify my work.

\section{Bibliography}

Abay, E., Dedeoğlu, F. 2005: 'Yılı Çivril Ovası Yüzey Araştırması 2005' Araştırma Sonuçları Toplantısı Cilt 1: 277-93

Appadurai, A. 1988: 'Introduction' in A. Appadurai (ed.), The Social Life of Things: Commodities in Cultural Perspective. Cambridge: 3-63

Bal, M., Bryson, N. 1991: 'Semiotics and art history' College Art Association of America 73: 174-208

Basedow, M.A. 2002: 'Cemetery and ideology in the west Anatolian coastal region' in R. Aslan, S. Blum, G. Kastl, F. Schweizer, D. Thumm (eds), Mauerschau. Festschrift für Manfred Korfman. Remshalden-Grunbach: 469-74

Bayne, N.P. 2000: The Grey Wares of North-West Anatolia in the Middle and Late Bronze Age and Early Iron Age and their Relation to the Early Greek Settlements. Bonn

Beckman, G. 1996: Hittite Diplomatic Texts. Atlanta

Beekes, R.S.P. 2003: 'Luwians and Lydians' Kadmos 42: 47-49

Bell, D., Valentine, G. 1997: Consuming Geographies: We Are Where We Eat. London and New York

Bliege Bird, R., Alden Smith, E. 2005: 'Signalling theory, strategic interaction, and symbolic capital' Current Anthropology 46: 221-48

Bourdieu, P. 1977: Outline of a Theory of Practice. Cambridge

Bryce, T.R. 1999: Kingdom of the Hittites. Oxford

- 2006: Trojans and Their Neighbours. London and New York

Butler, J. 1997: Excitable Speech: A Politics of the Performative. London and New York

Cline, E.H. 2008: "Troy as a "contested periphery": archaeological perspectives on cross-cultural and cross-disciplinary interactions concerning Bronze Age Anatolia' in B.J. Collins, M.R. Bachvarova, I.C. Rutherford (eds), Anatolian Interfaces: Hittites, Greeks and their Neighbours. Oxford: 11-20

Cohen, B. (ed.) 2000: Not the Classical Ideal: Athens and the Construction of the Other in Greek Art. Leiden

Collins, B.J. 2008: The Hittites and their World. Atlanta

Collins, B.J., Bachvarova, M.R., Rutherford, I.C. (eds) 2008: Anatolian Interfaces: Hittites, Greeks and their Neighbours. Oxford

Coombes, A.E. 1994: Reinventing Africa: Museums, Material Culture and Popular Imagination in Late Victorian and Edwardian England. London and New Haven

DeMarrais, E., Castillo, L.J., Earle, T. 1996: 'Ideology, materialization, and power strategies' Current Anthropology 37: 15-31 
Dietler, M., Hayden, B. 2001: Feasts: Archaeological and Ethnographic Perspectives on Food, Politics, and Power. Washington DC

Dinçol, A.M. 1998: 'Hatip Kaya Anıtının Keşfi ve Bunun Hitit Ülkesinin Tarihi ve Coğrafi Sorunlarına Etkileri' $T \ddot{U} B A-A R$ 1: 27-34

Dusinberre, E.R.M. 2003: Aspects of Empire in Achaemenid Sardis. Cambridge

Gamble, C. 2001: Archaeology: The Basics. London

Garstang, J., Gurney, O.R. 1959: The Geography of the Hittite Empire. London

Gates, M.-H. 2001: 'Potmarks at Kinet Hüyük and the Hittite ceramic industry’ Varia Anatolica 13: 13757

Glatz, C. 2006: Contact, Interaction, Control - The Archaeology of Inter-Regional Relations in Late Bronze Age Anatolia. PhD Thesis, University College London

- 2009: 'Empire as network: spheres of material interaction in Late Bronze Age Anatolia' Journal of Anthropological Archaeology 28: 127-41

Glatz, C., Matthews, R.J. 2005: 'Anthropology of a frontier zone: Hittite-Kaska relations in Late Bronze Age north-central Anatolia' Bulletin of the American Schools of Oriental Research 339: 47-65

Gosden, C. 2004: Archaeology and Colonialism: Cultural Contact from $5000 \mathrm{BC}$ to the Present. Cambridge

Grélois, J.-P. 1988: 'Les Annales décennales de Mursili II' Hethitica 9: 17-146

Gunter, A. 2006: 'Issues in Hittite ceramic production: a view from the western frontier' in D.P. Mielke, U.-D. Schoop, J. Seeher (eds), Strukturierung und Datierung der hethitischen Archäologie: Voraussetzungen - Probleme - Neue Ansätze. Internationaler Workshop Istanbul, 26-27 November 2004. Istanbul: 349-63

Gurney, O.R. 1975: The Hittites. Harmondsworth

Güterbock, H.G. 1983: 'Hittite historiography: a survey' in H. Tadmor, M. Weinfeld (eds), History, Historiography and Interpretation. Jerusalem: 21-31

Hall, E. 1989: Inventing the Barbarian: Greek SelfDefinition through Tragedy. Oxford

Hawkins, J.D. 1995a: The Hieroglyphic Inscription of the Sacred Pool Complex at Hattusa (Südburg). Wiesbaden

- 1995b: 'The political geography of north Syria and south-east Anatolia in the Neo-Assyrian period' in M. Liverani (ed.), Neo-Assyrian Geography. Rome: 87-101

— 1998: 'Tarkasnawa King of Mira, "Tarkondemos", Boğazköy sealings and Karabel' Anatolian Studies 48: $1-31$
- 2002: 'Anatolia: the end of the Hittite Empire and after' in E.A. Braun-Holzinger, H. Mattäus (eds), Die nahöstlichen Kulturen und Griechenland an der Wende vom 2. zum 1. Jarhtausend v. Chr. Mainz: 143-51

Heinhold-Kramer, S. 1977: Arzawa: Untersuchungen zu seiner Geschichte nach den hethitischen Quellen. Heidelberg

Hodder, I. (ed.) 1989: The Meaning of Things: Material Culture and Symbolic Expression. London and New York

Hodos, T. 2006: Local Responses to Colonization in the Iron Age Mediterranean. London and New York

Impey, O.R. 1977: Chinoiserie: The Impact of Oriental Styles on Western Art and Decoration. London

Jacobsen, D. 1993: Chinoiserie. London

Jones, S. 1997: The Archaeology of Ethnicity. London

Joukowsky, M.S. 1986: Prehistoric Aphrodisias. An Account of the Excavations and Artifact Studies. Louvain-la-Neuve

Keay, S., Terrenato, N. 2001: Italy and the West: Comparative Issues in Romanization. Oxford

Klengel, H. 2002: 'Problems in Hittite history, solved and unsolved' in K.A. Yener, H.A.J. Hoffner (eds), Recent Developments in Hittite Archaeology and History. Papers in Memory of Hans G. Güterbock. Winona Lake: 101-09

Knappett, C. 2005: Thinking Through Material Culture: An Interdisciplinary Perspective. Philadelphia

Lamb, W. 1936: 'Excavations at Kusura near Afyon Karahisar' Archaeologia 86: 1-64

Lloyd, S. 1954: 'Clues to the Arzawan Empire' The Times Newspaper 24 September. London

- 1955: 'The citadel of an ancient ruler: discoveries in Turkey' The Times Newspaper 28 June. London

- 1956: Early Anatolia: The Archaeology of Asia Minor before the Greeks. Harmondsworth

- 1972: Beycesultan. Vol. III. Part I. Late Bronze Age Architecture. London

Lloyd, S., Mellaart, J. 1955: 'Beycesultan excavations. First preliminary report' Anatolian Studies 5: 39-135

- 1956: 'Beycesultan excavations: second preliminary report' Anatolian Studies 6: 101-35

- 1957: 'An Early Bronze Age shrine at Beycesultan' Anatolian Studies 7: 27-35

- 1958: 'Beycesultan excavations: fourth preliminary report' Anatolian Studies 8: 93-125

- 1962: Beycesultan. Vol. I. The Chalcolithic and Early Bronze Age Levels. London

- 1965: Beycesultan. Vol II. Middle Bronze Age Architecture and Pottery. London

Lyons, C.L., Papadopoulos, J.K. 2002: The Archaeology of Colonialism. Los Angeles 
Mac Sweeney, N. 2009: 'Beyond ethnicity: the overlooked diversity of group identities' Journal of Mediterranean Archaeology 22/1: 101-26

Macqueen, J.C. 1975: The Hittites and their Contemporaries in Asia Minor. London

Matthews, R.J. 2000: 'Hittites and "barbarians" in the Late Bronze Age: regional survey in northern Turkey' Archaeology International 3: 32-35

Mellaart, J., Murray, A. 1995: Beycesultan. Vol. III. Part II. Late Bronze Age and Phrygian Pottery and Middle and Late Bronze Age Small Objects. London

Mora, C. 2003: 'On some clauses in the Kurunta Treaty and the political scenery at the end of the Hittite Empire' in G. Beckman, R. Beal, G. McMahon (eds), Hittite Studies in Honor of Harry A. Hoffner $J r$. Winona Lake: 289-96

Mountjoy, P. 1998: 'The east Aegean - west Anatolian interface in the Late Bronze Age: Mycenaeans and the Kingdom of Ahhiyawa' Anatolian Studies 48: 33-67

Pierson, S. 2007: Collectors, Collections and Museums: the Field of Chinese Ceramics in Britain, 1560 1960. Oxford

Rappaport, R. 1999: Ritual and Religion in the Making of Humanity. Cambridge

Renfrew, C. 1994: 'The archaeology of religion' in C. Renfrew, E. Zubrow, (eds), The Ancient Mind: Elements of Cognitive Archaeology. Cambridge: 47-54

Riva, C., Vella, N.C. 2006: Debating Orientalization: Multidisciplinary Approaches to Processes of Change in the Ancient Mediterranean. London

Rohrer, T. 2007: 'The body in space: embodiment, experientialism and linguistic conceptualisation' in T. Ziemke, J. Zlatev, R. Frank, R. Derven (eds), Body, Language and Mind. Berlin: 339-78

Sagona, A.G., Zimansky, P.E. 2009: Ancient Turkey. Abingdon

Schoop, U.-D. 2003: 'Pottery traditions of the later Hittite empire: problems of definition' in B.
Fischer, H. Genz, É. Jean, K. Köroğlu (eds), Identifying Changes: The Transition from Bronze to Iron Ages in Anatolia and its Neighbouring Regions. Istanbul: 167-78

— 2006a: 'Assyrer, Hethiter und Kaškäer - Zentralanatolien im zweiten Jahrtausend vor Christus' in M.O. Korfmann (ed.), Troia. Archäologie eines Siedlungshügels und seiner Landschaft. Mainz: 29-46

- 2006b: 'Dating the Hittites with statistics: ten pottery assemblages from Boğazköy-Hattuša' in D.P. Mielke, U-D. Schoop, J. Seeher (eds), Strukturierung und Datierung der hethitischen Archäologie: Voraussetzungen - Probleme - Neue Ansätze. Internationaler Workshop Istanbul, 26-27 November 2004. Istanbul: 215-39

Seeher, J. 2005: ‘Überlegungen zur Beziehung zwischen dem hethitischen Kernreich und der Westküste Anatoliens im 2. Jahrtausend v. Chr.' in B. Horejs, R. Jung, E. Kaiser, B. Terzan (eds), Interpretationsraum Bronzezeit. Bernhard Hänsel von seinen Schülern gewidmet. Bonn: 33-44

Tilley, C. 1989: 'Interpreting material culture' in I. Hodder (ed.), The Meaning of Things: Material Culture and Symbolic Expression. London and New York: 185-94

van Dommelen, P. 1998: On Colonial Grounds. A Comparative Study of Colonialism and Rural Settlement in First Millennium BC West Central Sardinia. Leiden

Vogelsang-Eastwood, G. 1990: 'Crescent loomweights?' Oriens Antiquus 29: 97-113

Wiessner, P. 1984: 'Reconsidering the behavioural basis for style: a case study among the Kalahari San' Journal of Anthropological Archaeology 3: 190234

Yakubovich, I.S. 2008: 'Luwian migration in light of linguistic contacts' in B.J. Collins, M.R. Bachvarova, I.C. Rutherford (eds), Anatolian Interfaces: Hittites, Greeks and their Neighbours. Oxford: 123-34 